\title{
Pelatihan 3M Pencegahan Penularan Covid-19 dengan Metode Bercerita untuk Anak Taman Kanan-Kanak Islam Terpadu (TKIT) Miftahussalam
}

\section{Training on 3M as a Prevention of Covid-19 Transmission with Storytelling Method for Children at the Integrated Islamic Kindergarten (TKIT) Miftahussalam}

\author{
Farida Noor Rohmah ${ }^{\mathbf{1}}$, Setya Putri Rahayu ${ }^{2}$ \\ ${ }^{12}$ Universitas 'Aisyiyah Yogyakarta - Jl. Ring Road Barat No.63 Area Sawa, Nogotirto, \\ Kec.Gamping, Kab. Sleman, Daerah Istimewa Yogyakarta 55592 \\ E-mail: faridanoor88@unisayogya.ac.id No.HP: 087839712447
}

Received: 15 September 2021; Revision: 20 Oktober 2021; Accepted: 02 November 2021

\begin{abstract}
Abstrak
Fakta yang ada dilapangan setelah diadakan observasi di TKIT Miftahussalam, didapatkan siswa sudah dijadwalkan untuk bersekolah secara tatap muka langsung seminggu satu kali. Walaupun terjadwal dan dibatasi jumlahnya, pada kenyataannya, masih ada beberapa anak yang lalai misalnya tidak memakai masker dengan benar dan tidak menjaga jarak serta enggan rajin mencuci tangan dengan sabun. Informasi tentang prorokol kesehatan sudah seringkali disampaikan oleh pihak sekolah akan tetapi masih ada anak yang enggan mempraktikkan. Permasalahan-permasalahan tersebut yang melatarbelakangi diadakannya pengabdian masyarakat yang bertema "Pelatihan Praktik 3M Pencegahan Penularan Covid-19 dengan Metode Bercerita untuk anak TKIT Miftahussalam." Output dari hasil pengabdian masyarakat ini adalah, pengetahuan dan kesadaran anak-anak TKIT Miftahussalam tentang pentingnya 3M terutama di lingkungan sekolah meningkat. Akan tetapi, masih diperlukan dukungan dari orang tua dan lingkungan rumah.
\end{abstract}

Kata Kunci: 3M; Covid-19; Metode Bercerita, Anak Usia Dini

\begin{abstract}
Based on the observations at TKIT Miftahussalam, it was found that students were scheduled to attend school face-to-face once a week. Although limited in number, in fact, there are still some students who are negligent, for example, did not wear masks properly and did not keep their distance and were reluctant to frequently wash their hands with soap. Despite the school's repeated communication of health protocols, some students were still hesitant to put them into effect. The community service was themed "3M Practice Training for the Prevention of Covid-19 Transmission using the Storytelling Method for TKIT Miftahussalam Students" in response to these problems. The output of the results of this community service were the knowledge and awareness of TKIT Miftahussalam students about the importance of $3 M$, especially in the school environment. However, parental support and the home environment are still required.
\end{abstract}

Keyword: 3M; Covid-19; Storytelling Method, Early Childhood

Rohmah, F., \& Rahayu, S. (2021). Pelatihan 3M Pencegahan Penularan Covid-19 dengan Metode Bercerita untuk Anak Taman Kanan-Kanak Islam Terpadu (TKIT) Miftahussalam. Masyarakat Berdaya dan Inovasi, $2(2), 118$ 124. doi:https://doi.org/10.33292/mayadani.v2i2.68 


\section{PENDAHULUAN}

Penyebaran Covid-19 di Indonesia semakin hari semakin menunjukkan angka peningkatan yang pesat. Kasus konfirmasi positif pun merata di semua lapisan umur, baik orang dewasa bahkan anakanak. Menurut data satgas penanganan Covid-19, secara kumulatif hingga 16 juli 2021 ada 777 anak di indonesia meninggal dunia akibat Covid-19. Persentase angka kematian tertinggi (CFR) berada pada kelompok usia 0-2 tahun, diikuti kelompok usia 16-18 tahun dan usia 3-6 tahun. Hingga 16 Juli 2021, sebaran kasus Covid-19 pada usia anak sekolah mencapai 12,83 persen dari seluruh kasus terkonfirmasi positif di Indonesia (LITHA, 2021). Berbagai upayapun sudah dilakukan pemerintah dalam rangka menekan peningkatan kasus positif Covid-19. Sampai saat ini ada tiga strategi yang sudah dirumuskan pemerintah. pertama, percepatan vaksin; kedua, pemberlakuan PPKM di Jawa dan Bali dan ketiga, tentu saja masyarakat dituntut untuk menerapkan pola hidup tertentu (protokol) untuk menghindari penularan yakni memakai maskern dengan benar, mencuci tangan pakai sabun, dan menjaga jarak (3M). Bahkan sudah ada beberapa tambahan protocol lain seperti menjauhi kerumunan dan melakukan vaksinasi.

Upaya menghadirkan gerakan 3M secara konkrit di semua lapisan masyarakat, dari orang dewasa hingga termasuk juga anak-anak perlu dilakukan selain mengkampanyekan gerakan 3M diberbagai media. Anak usia sekolah terutama anak usia dini kisaran 5 sampai 7 tahun merupakan kelompok usia yang kritis, karena pada usia tersebut seorang anak rentan terhadap masalah kesehatan. Selain itu, anak-anak tidak sedikit yang masih sulit untuk dikontrol terkait penerapan 3M, misalnya bekerumun, tidak memakai masker dengan benar dan mencuci tangan dengan cara yang masih belum benar. Walaupun pada dasarnya, anak usia sekolah juga berada pada kondisi yang sangat peka terhadap stimulus sehingga mudah dibimbing, diarahkan, dan ditanamkan kebiasaan-kebiasaan yang baik, termasuk kebiasaan berprilaku hidup bersih dan sehat. Pada umumnya, anak-anak seusia ini juga memiliki sifat selalu ingin menyampaikan apa yang di terima dan diketahuinya dari orang lain. Oleh sebab itu, praktik 3M dirasa perlu dilakukan latihan dan kebiasaan sehingga mereka akan terbiasa.

Fakta yang ada dilapangan setelah diadakan observasi TKIT Miftahussalam Kecamatan Mlati Kabupaten Sleman, didapatkan fakta bahwa sekolah sudah akan melaksanakan sekolah tatap muka dengan siswa dating ke sekolah mulai tahun ajaran baru 2021. Walaupun jumlah siswa dibatasi dan dbagi menjadi beberapa shift, akan tetapi pada kenyataannya di lapangan masih ada beberapa anak yang lalai misalnya tidak memakai masker dengan benar dan tidak menjaga jarak serta enggan rajin mencucui tangan dengan sabun. Permasalahan-permasalahan tersebut yang melatarbelakangi diadakannya pengabdian masyarakat yang bertema "Pelatihan Praktik 3M Pencegahan Penularan Covid-19 dengan metode bercerita untuk anak TKIT Miftahussalam.”

Metode bercerita digunakan karena sesuai dengan karakter siswa TK atau anak usia dini. Bercerita merupakan salah satu metode dan teknik bermain yang banyak dipergunakan di TK. Bercerita merupakan salah satu pemberian pengalaman belajar bagi anak dengan membawakan cerita kepada anak secara lisan. Cerita yang digunakan harus menarik, dan mengundang perhatian anak dan tidak terlepas 
dari tujuan pendidikan bagi anak (Moeslichatoen, 2004). Sedangkan (Anggraini, 2015) mengemukakan bahwa cerita memiliki arti penting bagi Pendidian Anak Usia Dini, bercerita merupakan alat pendidikan budi pekerti yang mudah dicerna anak, memberikan efek psikologis yang positif bagi anak dan guru, membangkitkan rasa ingin tahu anak, memberikan daya tarik bersekolah bagi anak dan mendorong anak memberikan makna bagi proses belajar. Berdasarkan paparan diatas, maka penerapan metode bercerita pada anak usia dini lebih dirasa menyenangkan oleh anak karena anak lebih senang mendengarkan cerita daripada mendengarkan ceramah dari gurunya

Metode bercerita disampaikan melalui cerita yang menarik dapat dengan atau tanpa bantuan media pembelajaran. Cerita yang disampaikan hendaknya mengandung pesan, nasihat, dan informasi yang dapat ditangkap oleh anak, sehingga anak dapat dengan mudah memahami cerita serta meneladani hal-hal baik yang terkandung di dalam isi cerita yang telah disampaikan. Materi dan pelatihan tenatng praktik 3M untuk pencegahan penyebaran Covid-19 diharapkan dapat diserap oleh siswa TK dengan lebih mudah dengan penyampaian materi menggunakan metode bercerita berbantuan buku bergambar.

TKIT Miftahusslam sendiri berdiri sejak tahun 2002. Saat ini TKIT Miftahusslam terdiri dari 5 kelas anak usia 5-6 tahun berjumlah 58 anak. Guru yang mengajar berjumlah 6 dan 1 kepala sekolah dengan latar belakang mayoritas S1 PAUD. Kegiatan belajar mengajar selama pandemi mayoritas menggunakan system daring akan tetapi mulai diterapkan system luring mulai ajaran baru 2021 di sekolah yang beralamatkan di Jl. Lukito Harjo, Karanggeneng, Sendangadi, Mlati, Sleman. Masalah yang ditemukan di lapangan adalah sebagai berikut.

1. Pengetahuan anak-anak TKIT Miftahussalam tentang 3M masih belum baik, masih ada anak yang belum paham.

2. Anak-anak TKIT Miftahussalam masih belum mempraktikkan 3M dengan benar ketika melakukan kegiatan luring.

3. Metode penyampaian atau penyuluhan masih kurang bisa dipahamai semua anak.

Berdasarkan pemaparan analisis situasi dan permasalahan mitra di atas, maka solusi atau upaya yang dapat dilakukan adalah: Pemberian pelatihan praktik 3M kepada anak-anak TKIT Miftahussalam dengan metode bercerita. Pelatihan ini diberikan kepada anak-anak TKIT Miftahussalam tentang apa itu $3 \mathrm{M}$ dan bagaimana cara menpraktikkannya. Pengetahuan anak tentang $3 \mathrm{M}$ masih belum baik sehingga memiliki resiko cukup tinggi untuk rentan terkena masalah kesehatan termasuk wabah Covid-19 ini. Pengetahuan dan pemahaman tentang praktik 3M dirasa dapat mengurangi resiko tersebut.

\section{METODE}

Kegiatan yang dilakukan dalam pengabdian masyarakat ini meliputi:

\section{a. Tahap Persiapan}

Pada tahap ini dilakukan beberapa kegitan adalah: melakukan analisis situasi dengan cara mewawancarai Kepala Sekolah TKIT Miftahussalam, melakukan perijinan dengan pihak mitra, 
melakukan sosialisasi dengan mitra terkait rencana kegiatan, melakukan persiapan bahan pencarian dan pembuatan materi pelatihan, melakukan persiapan alat, melakukan publikasi kepada sasaran kegiatan dengan membuat undangan Zoom Conference yang kita sebar melalui Whatsapp Group orang tau wali murid.

\section{b. Tahap Pelaksanaan Kegiatan}

Tahap pelaksanaan kegiatan yaitu pelaksanaan Pelatihan Praktik 3M pencegahan penyebaran Covid19 yaitu menjelaskan gambaran umum kegiatan, menjelaskan ap aitu virus corona dan cara praktik $3 \mathrm{M}$ dengan metdode bercerita.

\section{c. Tahap Evaluasi}

Pada tahap ini dilakukan beberapa kegiatan evaluasi yaitu: melakukan dokumentasi kegiatan, mengajukan pertanyaan lisan terkait bahan pelatihan dengan mengadakan quiz berhadiah yang menarik bagi anak-anak, melakukan diskusi singkat tentang jalannya pelatihan, melakukan follow up tentang aplikasi materi.
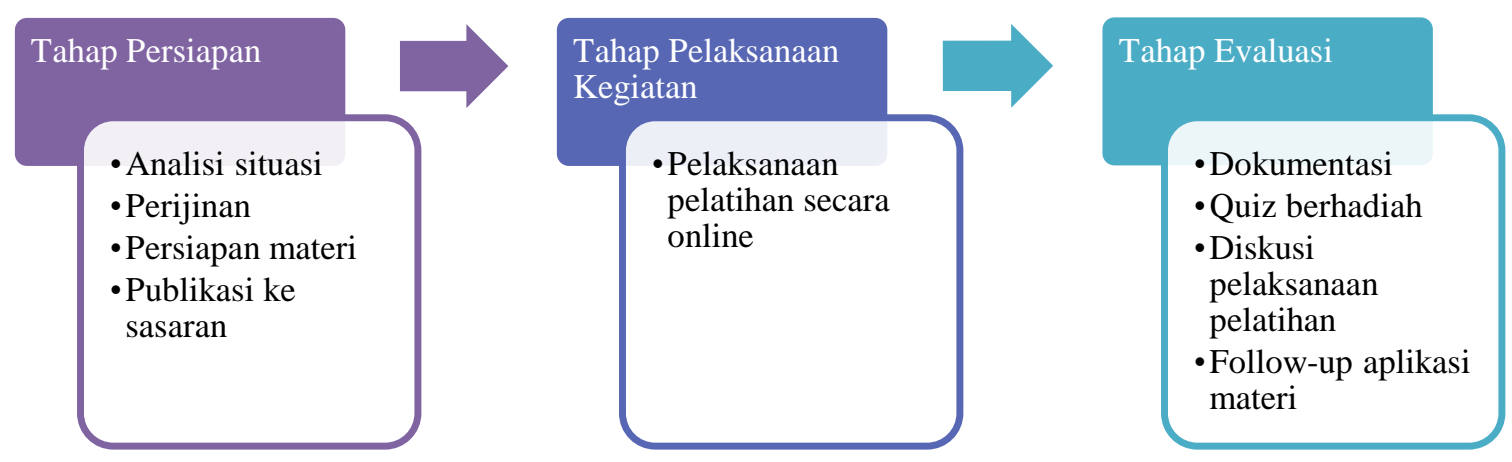

Gambar 1. Alur kegiatan pengabdian masyarakat

\section{HASIL DAN PEMBAHASAN}

Kegiatan pelatihan Praktik 3M Pencegahan Penyebaran Covid-19 ini dilaksanakan secara daring dengan menggunakan platform Zoom Conference. Pelaksanaan pelatihan dilaksanakan dengan system daring setelah berdiskusi dengan pihak sekolah yaitu Ibu Dra. Haryanti selaku Kepala Sekolah TKIT Miftahussalam. System pelatihan daring dilaksanakan karena di DIY masih ada peraturan PPKM yang membatasi mobilitas masyarakat termasuk membatasi pertemuan luring yang berpotensi membuat kerumunan massa. Platform Zoom dipilih karena orang tua wali sudah familiar menggunakannya untuk sekolah system daring. Di sekolah mitra pengabdian sudah menggunakan platform zoom satu kali seminggu untuk kelas daring. 
Pelaksanaan pelatihan ini diawali dengan observasi awal pada bulan Juni 2021. Pelaksana pengabdian mewawancarai langsung Kepala Sekolah Ibu Dra. Haryanti. Wawancara dilakukan dengan tujuan menggali permasalahan yang mereka hadapi. Dari wawancara, dapat disimpulkan bahwa permasalahan yang sering mereka hadapi di masa pandemic ini adalah kurangnya pengetahuan dan kesadaran siswa tentang protocol kesehatan 3M (memakai masker dengan benar, mencuci tangan memakai sabun, dan menjaga jarak). Permasalahan kurangnya pengetahuan dan kesadaran siswa tersebut disebabkan karena metode penyampaian protocol masih bersifat instruksi-instruksi yang sedikit sulit dipahami oleh anak usia dini.

Setelah diadakan observasi awal dan diskusi dengan pihak mitra dan ditemukan permasalahan, pelaksana pengabdian kemudian merumuskan kegiatan pengabdian, dengan kegiatan awal mencari dan mengumpulkan materi-materi untuk pelatihan. Materi pelatihan berisi tentang pengenalan virus corona dan cara pencegahannya. Metode penyampaian dipilih berdasarkan landasan teori dan permasalahan yang ditemukan bahwa anak-anak lebih mudah menerima materi dengan metode bercerita karena lebih menarik perhatian. Untuk itu, pelaksana pengabdian memilih buku bergambar sebagai media untuk menyampaikan cerita tentang virus corona tersebut. Tingkat kesulitan buku cerita juga disesuaikan dengan kemampuan siswa anak usia dini. Setelah itu, didapatkan buku cerita bergambar yang sesuai dengan tema dan tujuan pelatihan. Buku bergambar yang digunakan tidak dalam bentuk hardcopy melainkan dalam bentuk e-book yang dibuka dengan aplikasi flipbook Fliphtml5. Aplikasi ini terlihat lebih menarik dibuka karena bisa menampilkan e-book dalam bentuk 3D sehingga lebih menarik bagi anak-anak. Gambaran tampilan e-book bisa dilihat dari gambar berikut ini:

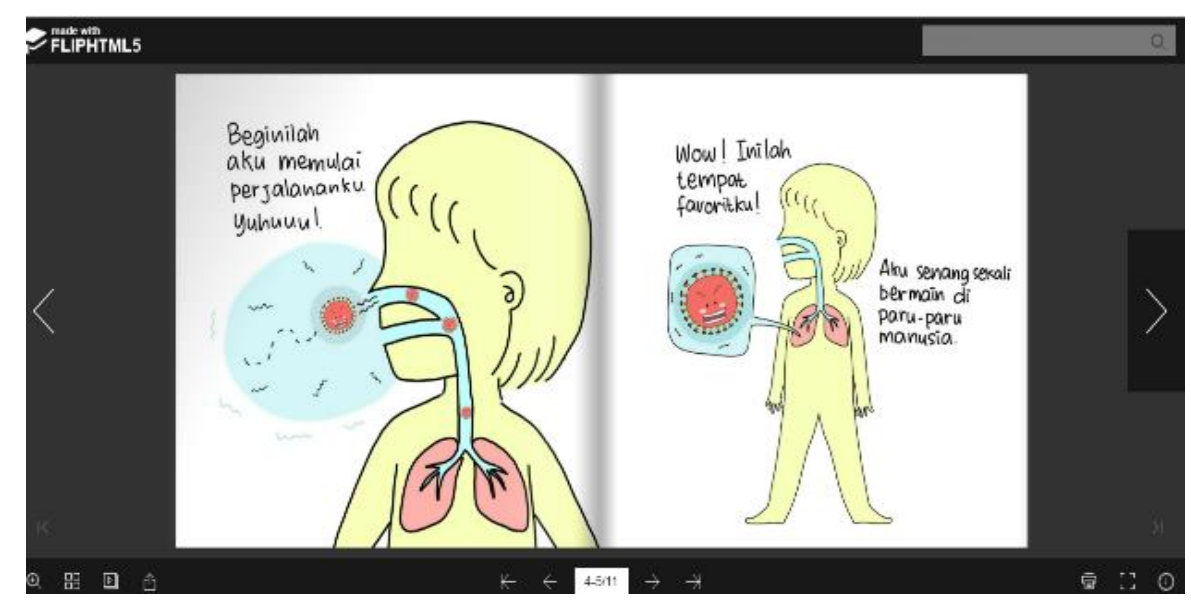

Gambar 2. Tampilan e-book cerita bergambar (Beranda Kawal Covid19, 2021) 
Materi pelatihan secara garis besar dapat dilihat pada table berikut:

Table 1. Topik-topik pada Materi Pelatihan

\begin{tabular}{|l|l|}
\hline \multicolumn{1}{|c|}{ Judul buku } & \multicolumn{1}{c|}{ Fokus materi } \\
\hline Cerita Si Korona & Pengenalan apa itu virus corona \\
Perjalanan Si Korona & Bagaimana virus corona masuk ke tubuh manusia \\
& sehingga membuat manusia menjadi sakit \\
Pakailah Masker dengan Benar & Cara memakai masker dengan benar \\
Ayo Cuci Tangan Dulu & Cara mencuci tangan dengan benar \\
Saling Sapa dari Rumah & Himbauan menjaga jarak dan menghindari kerumunan \\
\hline
\end{tabular}

Sumber diolah dari : (Beranda Kawal Covid19, 2021)

Setelah materi, pelaksana pengabdian berdiskusi dengan Kepala Sekolah untuk mentukan tanggal pelatihan. Tanggal pelatihan kemudian dilakukan diluar jadwal tetap kelas zoom sekolah. Pelatihan yang bertemakan Praktik 3M tersebut dilaksanakan pada hari Jumat, tanggal 3 September 2021. Pelatihan dilaksanakan kurang lebih selama 90 menit, mulai pukul 09.00-10.30 WIB melalui Zoom Conference. Kegiatan pelatihan diawali dengan pembukaan oleh salah satu guru TKIT Miftahusslalam. Kemudian penyampaian materi disampaikan oleh 2 dosen pelaksana pengabdian yaitu Farida Noor Rohmah dan Setya Putri Rahayu. Cerita pertama dibuka dengan buku "Cerita Si Korona" dan "Perjalanan Si Korona" dengan tujuan agar siswa benar-benar mengerti ap aitu virus corona dan bagaimana virus corona masuk ke dalam tubuh manusia sehingga membuat manusia menjadi sakit. Materi selanjutnya yaitu bercerita dengan bantuan buku "Pakailah Masker dengan Benar", "Ayo Cuci Tangan Dulu" dan "Saling Sapa dari Rumah" dengan tujuan meningkatkan pemahaman anak tentang protocol kesehatan 3M yang harus dilakukan untuk mencegah penyebaran virus corona. Setelah bercerita, anak-anak diajak untuk mempaktikkan protokol kesehatan tersebut bersama-sama. Setelah cerita-cerita disampaikan, anak-anak diajak untuk bermain quiz tebak-tebakan yang bertujuan untuk mengukur pemahaman anak setelah diberikan pelatihan. Quiz dipuandu oleh mahasiswa fiisoterapi Universitas 'Aisyiyah Yogyakarta yaitu Anggita, Amelia dan Nikma. Agar anak lebih tertarik maka anak yang berhasil menjawab pertanyaan diberikan souvenir. Pertanyaan-pertanyaan quiz dibuat mudah tetapi bisa mengukur pemahaman anak. Misalnya: anak diminta mempraktikkan memakai masker dengan benar dan Langkah mencucin tangan dengan benar.

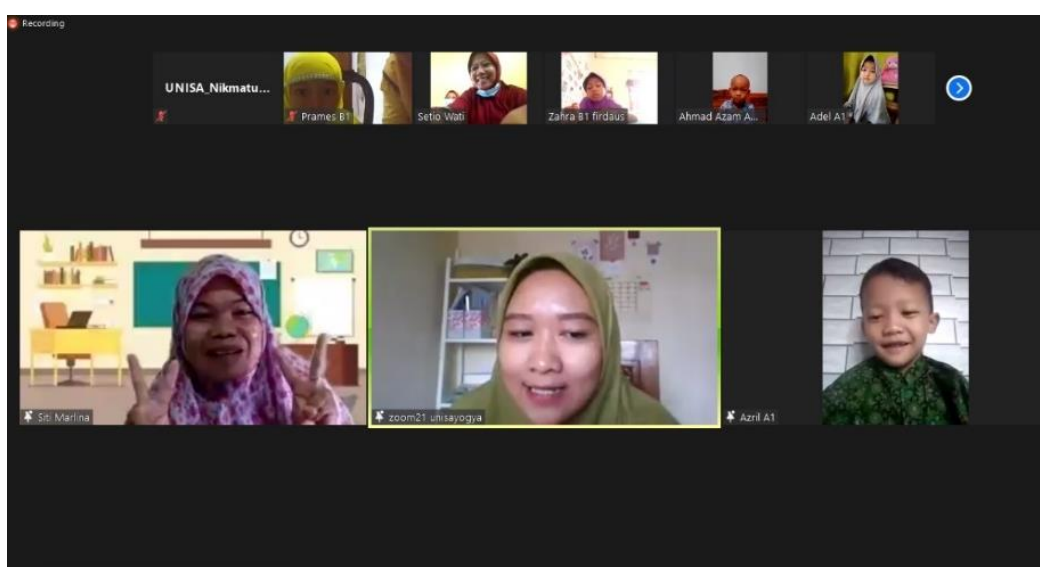

Gambar 3. Kegiatan pelatihan daring 
Hasil penilaian dari observasi selama pelatihan terhadap peserta pelatihan diperoleh informasi sebagai berikut:

a. Perhatian peserta sangat baik ditandai dengan keseriusan pada saat mengikuti pelatihan dan terlihat dari keaktifan peserta sesi bercerita maupun quiz.

b. Pemahaman anak selama mendengarkan cerita pada pelatihan ini baik. Hal ini sejalan dengan yang disampaikan (Dhieni, Fridana, Muis, Yarmi, \& Wulan, 2014), tujuan bercerita bagi anak usia 4-6 tahun adalah agar anak mampu mendengarkan dengan seksama terhadap apa yang disampaikan orang lain, anak dapat bertanya apabila tidak memahaminya, anak dapat menjawab pertanyaan, selanjutnya anak dapat menceritakan dan mengekspresikan terhadap apa yang didengarkan dan diceritakannya, sehingga hikmah dari isi cerita dapat dipahami dan lambat laun didengarkan, diperhatikan, dilaksanakan dan diceritakannya pada orang lain. Setelah mendengarkan cerita, anak menjadi lebih memahami virus corona dan cara pencegahannya untuk kemudian bisa dipraktikkan di kehidupan sehari-hari sesuai dari nilai dan hikmah yang mereka ambil dari cerita yang disampaikan.

\section{SIMPULAN}

Kegiatan pengabdian ini penting untuk dilakukan karena urgensi kesehatan di masa pendemi adalah yang utama, anak-anak dibekali dengan pengetahuan yang baik tentang pencehagan virus corona menggunakan 3M dan protocol kesehatan agar ketika mereka sudah melaksanakan sekolah secara luring, mereka tetap patuh protocol dan terhindar dari virus corona. Kegiatan pengabdian ini dilaksanakan dengan lancer, peserta pelatihan antusias mendengarkan dan secara aktif bertanya, meskipun kegiatan pengabdian ini dilakukan di lingkungan sekolah dan berjalan dengan tertib, dengan melibatkan guru, perlu adanya dukungan dari keluaga terutama orang tua.

\section{UCAPAN TERIMA KASIH}

Tim pengabdian masyarakat berterimakasih kepada LP2M Universitas 'Aisyiyah Yogyakarta, Kepala sekolah dan guru-guru TKIT Miftahussalam yang telah membantu dalam proses pelaksanaan pengabdian dan memberikan dukungannya.

\section{DAFTAR PUSTAKA}

Anggraini, D. D. (2015). Peningkatan Pengembangan Nilai Agama dan Moral Melalui Metode Bercerita. Jurnal PG-PAUD Trunojoyo, 76-148.

Beranda Kawal Covid19. (2021). Retrieved from Kawal Covid19: https://kawalcovid19.id/

Dhieni, N., Fridana, L., Muis, A., Yarmi, G., \& Wulan, S. (2014). Metode Pengembangan Bahasa. Tangerang Selatan: Universitas Terbuka.

Litha, Y. (2021, July 21). Covid-19: VOA Indonesia. Retrieved from VOA Indonesia : https://www.voaindonesia.com/a/ribu-anak-di-indonesia-terpapar-covid-19/5974016.html

Moeslichatoen, R. (2004). Metode Pengajaran di Taman Kanak-Kanak. Jakarta: Rineka Cipta. 